\title{
Culture and Planning for Change and Continuity in Botswana
}

Journal of Planning Education and Research $X X(X) 1-16$

(C) The Author(s) 2012

Reprints and permission: http://www. sagepub.com/journalsPermissions.nav DOI: | 0.1 | 177/0739456X | |4355 | |

http://jpe.sagepub.com

(S)AGE

\section{Feras Hammami'}

\begin{abstract}
This paper examines how culture might be integrated in planning by critically rethinking the role of planners and knowledge in the planning systems of postcolonial contexts. The empirical study of cultural conception and utilization in Botswana suggests a shift from planning for culture to cultural institutionalization, where culture, rather than as an object, becomes integral to development planning decisions. The traditional division between bottom-up and top-down approaches is challenged, so as to allow a wider range of actors and views to interact during the entire planning process.
\end{abstract}

\section{Keywords}

cultural conservation, cultural landscape, postcolonial societies, Tswana culture

\section{Introduction}

While the importance of culture in development planning is argued convincingly in global governance discourse, urban and regional planning has not yet embraced a similar vision. Most planning models seem to represent only limited variations of the traditional top-down and bottom-up paradigms, which do not include an emerging view of culture as dynamic (Gibson and Pendlebury 2009; Young 2008). Within the international debate on the relationship between culture and planning, integrated conservation emerged by the end of the $1970 \mathrm{~s}$ in the European context as a crosssectorial approach to promote culture as an integral ingredient of development policies (Jokilehto 2004; UNESCO 2003; Mason 2002; Arizpe 1997). Other community-led approaches of planning for culture also proliferated in the early 1990s, enhanced by the growing sustainability discourse (UNESCO 2000, 21ff). In such approaches, local forms of knowledge are integrated from the early stages of planning for culture to resolve broader community issues (Young 2008; Mills 2003; Dreeszen 1997; Bianchini and Ghilardi 1997).

In postcolonial societies, culture is incorporated in planning in a substantially different way from those in a Western context. Many African governments have either inherited and retained the planning system of their former colonial powers or imported other foreign planning models, without sufficient attention to their contextual relevance (Watson 2003; Mbembe 2001). Postcolonial assistance programs from the West to African countries also have been driven by certain economic ideologies (Hyden et al. 2004). Western experts (such as planners, architects, and civil engineers) and technology (such as planning tools, legislations, and development toolkits) became prevalent in the recipient countries, to ensure the replication of institutions and techniques proven successful in modernizing the industrialized world (Hyden et al. 2004; Mbembe 2002; Rapley 1996). In Botswana, this has resulted in a planning system divorced from the local culture as well as built environments characterized by Western images, without roots in the native cultural identity and social context. While some Batswana find in such development the essential characteristics of "modernization," others find it intrusive.

This paper examines how culture might be integrated in planning by critically rethinking the role of planners and knowledge in postcolonial Botswana's planning system. Two sites were selected for field research: Shoshong village and Sowa town. Shoshong, a long established village, allowed for an indepth analysis of a traditional Tswana living context. Sowa, a newer town, was initially planned and designed based on the Tswana cultural landscape (interviews: Wåreus, June 2007, and Mosha, May 2007; see appendix) and was selected to examine how culture was interpreted by its town planners and whether the resulting cultural functionality worked as planned. "Tswana" here refers to the dominant culture in Botswana. It represents the way of life, customs, and the general appearance of the built environment. There was no intention to select a case that represents a dominant culture. However, Tswana, which forms the

Initial submission, June 2009; revised submissions, April and November 201 I; final acceptance, December 201 I

'Royal Institute of Technology, Stockholm, Sweden

\section{Corresponding Author:}

Feras Hammami, Division of Urban and Regional Studies, Royal Institute of Technology, Drottning Kristinas väg 30, I I 428 Stockholm, I0040, Sweden Email: feras.hammami@abe.kth.se 
spatial morphology of most of Botswana's villages, was the context initially considered by Sowa's town planners.

The study findings reveal dramatic sociocultural changes in Tswana built environments, increasingly produced and reproduced through instruments designed in and for a foreign context. Given that social spaces cannot be produced through conventional planning models without being contextualized, this paper calls for cultural institutionalization, where the conception and utilization of culture become an intrinsic process backed by a wide range of actors, powers, and views during the entire planning process. It is also hoped that this study contributes to an ongoing review of the planning system recently initiated by the government of Botswana.

\section{Culture in Planning Living Environments}

Culture, in this paper, refers to the cultural landscape of a living environment, where the physical (buildings and other spatial elements) and soft (lifestyle, traditions, and ways of living) constituents of inhabited areas are interlinked and equally significant. Culture, often a contentious issue, is increasingly thought of as lived experience rather than an artistic production and the realm of specialist knowledge (Williams 1958, 1966). According to Williams (1958), culture has two aspects: the meanings and directions familiar to its members, and the observations and meanings that can be considered by those outside of it. Thus, the constituents, meanings, and values of culture are changeable and continually reconstructed through the webs of relations between people and their physical environment (Gibson 2009; cited in Gibson and Pendlebury 2009, 71).

In practice, current planning models tend to overlook the authentic and lived experiences of culture because of its complex and dynamic nature, or because of the inability of rigid development planning models to respond to continuous contextual changes (Young 2008). Within the international development context, the presentation of integrated conservation in the European Charter of Architectural Heritage (Council of Europe 1975a), the Amsterdam Declaration (Council of Europe 1975b) and United Nations Educational, Scientific and Cultural Organization (UNESCO) recommendations concerning historic areas (UNESCO 1976) enabled better recognition of the physical and soft aspects of culture in urban policies. In some countries, byelaws were enacted in order to change the perception of the cultural landscape from a focus on individual objects to the built environment, and to change cultural management from safeguarding to cross-sectorial policies. This involves reconciling conservation requirements and planning objectives through coordinated strategies administered by professionals and public agencies (Engelbrektsson and Rosvall 2003).

However, the proponents of integrated conservation subordinate public participation to the opinion of experts. Participants also are required to present their arguments on a scientific basis. In reality, the public cannot be expected to argue scientifically, yet "they are contrasted with 'the experts', pushed into the role of beneficiaries, and thus made passive" (Gibson 2009, 75; cited in Gibson and Pendlebury 2009). Obviously, such an expert-led approach limits the role of local knowledge in the cultural assessment of living environments. It may therefore frame culture not as a dynamic concept but as an artistic product of the past that requires "conservation." Public participation where experts tend to inform people rather than partner with them can be seen, in this paper, as decentralized top-down planning.

In contrast to integrated conservation, other bottom-up approaches of planning for culture focus on integrating local knowledge from the earliest stages of planning (Mercer 2002, $18 \mathrm{ff})$. Such approaches involve inclusive community dialogues to determine the public needs and preferences, and to discover existing resources and opportunities for planning social spaces. To their proponents, the aim of such approaches is to change the art-laden meaning of culture into one relating to local contexts, and to address culture not as a mere object but as an integral process in planning (Mercer 2006; Baeker and Cardinal 2001; McNulty 1991). However, some criticize such approaches for the attention they give to local community members at the expense of planning and heritage practitioners. They are also regarded as inefficient, slow, and a hindrance to the policy-making process. Nevertheless, they seem to challenge current planning models with the call they make for building idealistic capacity, and are able to perceive the broad meanings and potentials of culture produced by community dialogues. This kind of community-centered participation is regarded, in this paper, as decentralized bottomup planning.

In spite of the different approaches, both integrated conservation and planning for culture call for better integration of culture into the planning process. They also respond to the increasingly complex relationship between culture and planning, as well as to the growing value that local knowledge has in making development planning decisions. However, both seem to keep a distinct division between experts and the public, working either as a top-down or bottom-up process. This division ${ }^{1}$ equally embraces a vertical link to inform the other side, rather than partner it as an interactive actor. Such an interactive actor would be an integral part of the process rather than passively engaged as a beneficiary.

\section{The Cases: Selection, Context and Conduct}

Two study areas in Botswana were selected for field research: Shoshong village and Sowa town, whose locations within Botswana are shown in Figure 1. While Shoshong represents a Tswana built environment, Sowa is a modern town designed and planned based on Tswana culture. Comparing the two development contexts opens critical discussions on how culture has been integrated in the planning of Sowa and how planning ideas developed in Western culture have been exported to a Tswana cultural context and eventually materialized in the cur- 


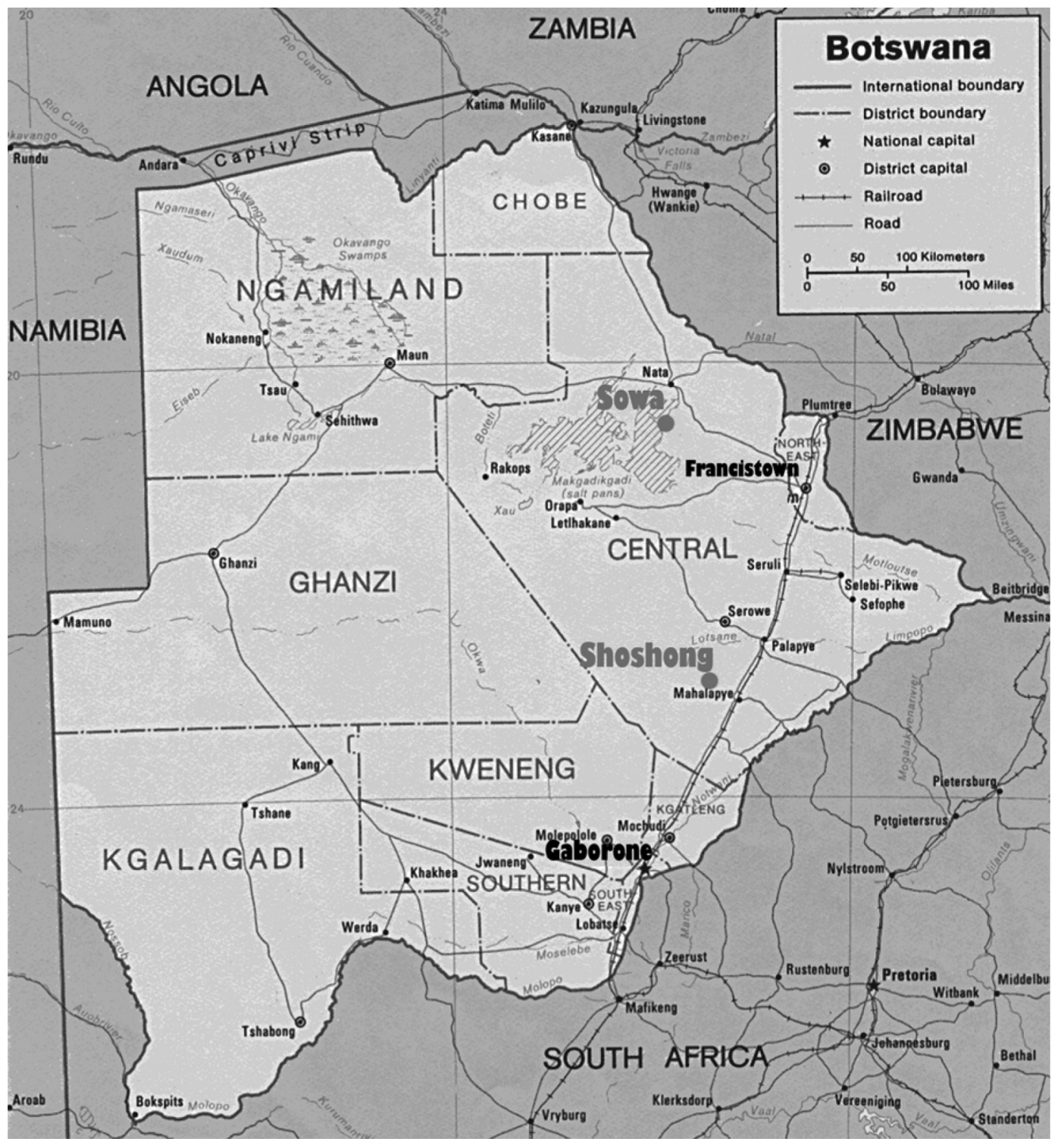

Figure I. Sowa town and Showing village in Botswana

Source: The Department of Survey and Mapping, Botswana

rent built environment of Sowa. Such discussions also unfold the possible spatial and social consequences for the way culture is integrated in planning.

\section{Shoshong Village}

Shoshong village dates back to 1850 . According to the Master Plan of Shoshong (2005), the estimated population is eighteen thousand. The village is today inhabited and spatially organized by three tribes: the Bangwato, the Baphaleng, and the Bakaa. Each tribe lives in a number of wards, each ward being a distinct unit that groups settlement households in a horseshoe layout centered on a patlelo (an open, semipublic space shared by ward households; Figure 2) (Kalabamu and Thebe 2005, 12). Figure 3 shows the layout of Shoshong and of a typical ward. The chief's ward (kgosing) occupies a central location in the village, around the great tribal meeting space, the kgotla. The other royal wards are placed around the kgotla, and the higher their status the closer they are to the kgosing. Then the wards of commoners radiate out in a circle. The wards of the lowest standing are on the outskirts, or in small outlying villages that generally contain only a few 


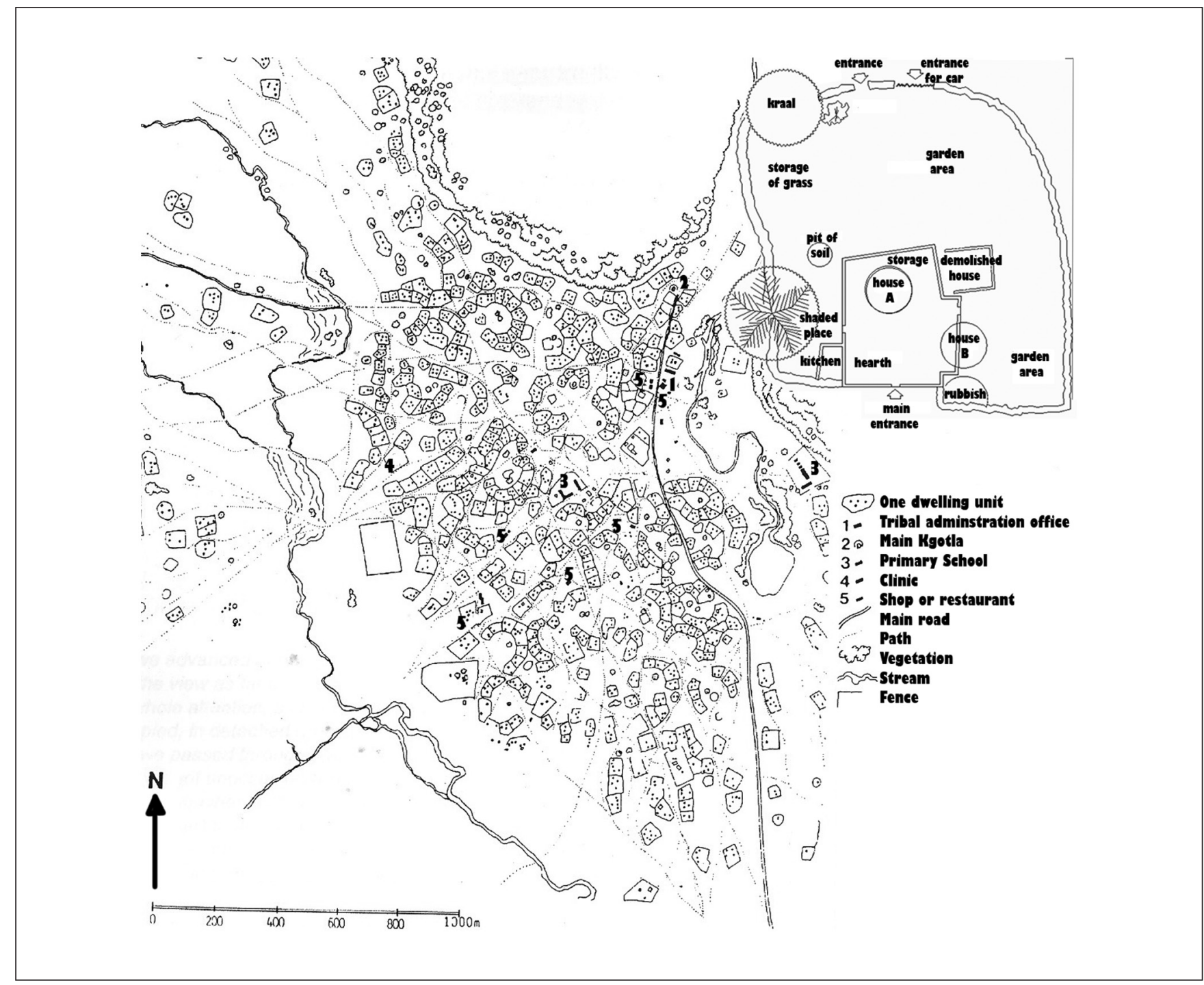

Figure 2. Map of Shoshong (left) and the spatial arrangement at a plot level (right) Source: Department of Surveys and Mapping (left); and Larsson and Larsson (1984) (right)

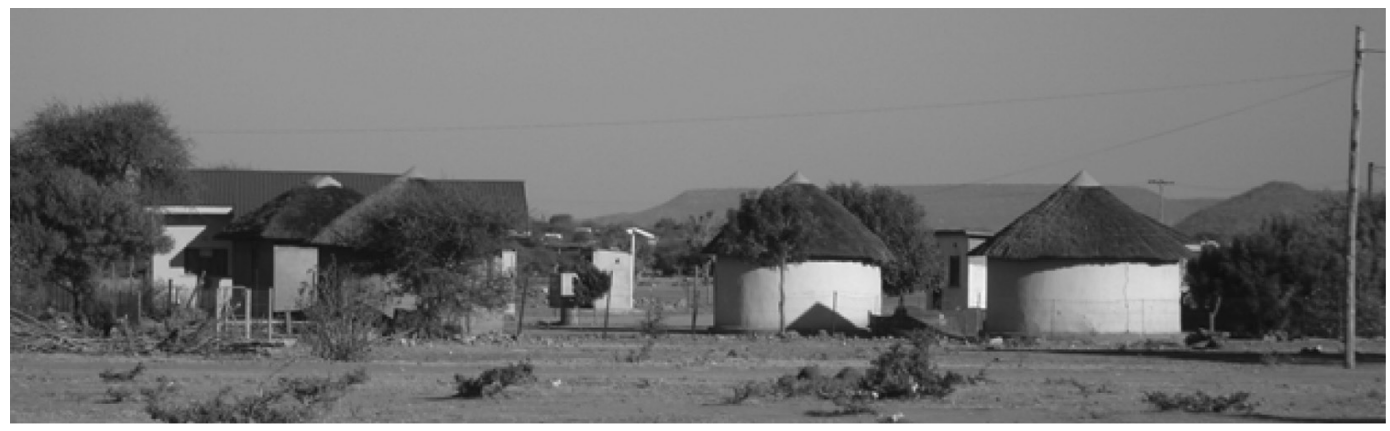

Figure 3. Typical housing units in Shoshong Source: Author 


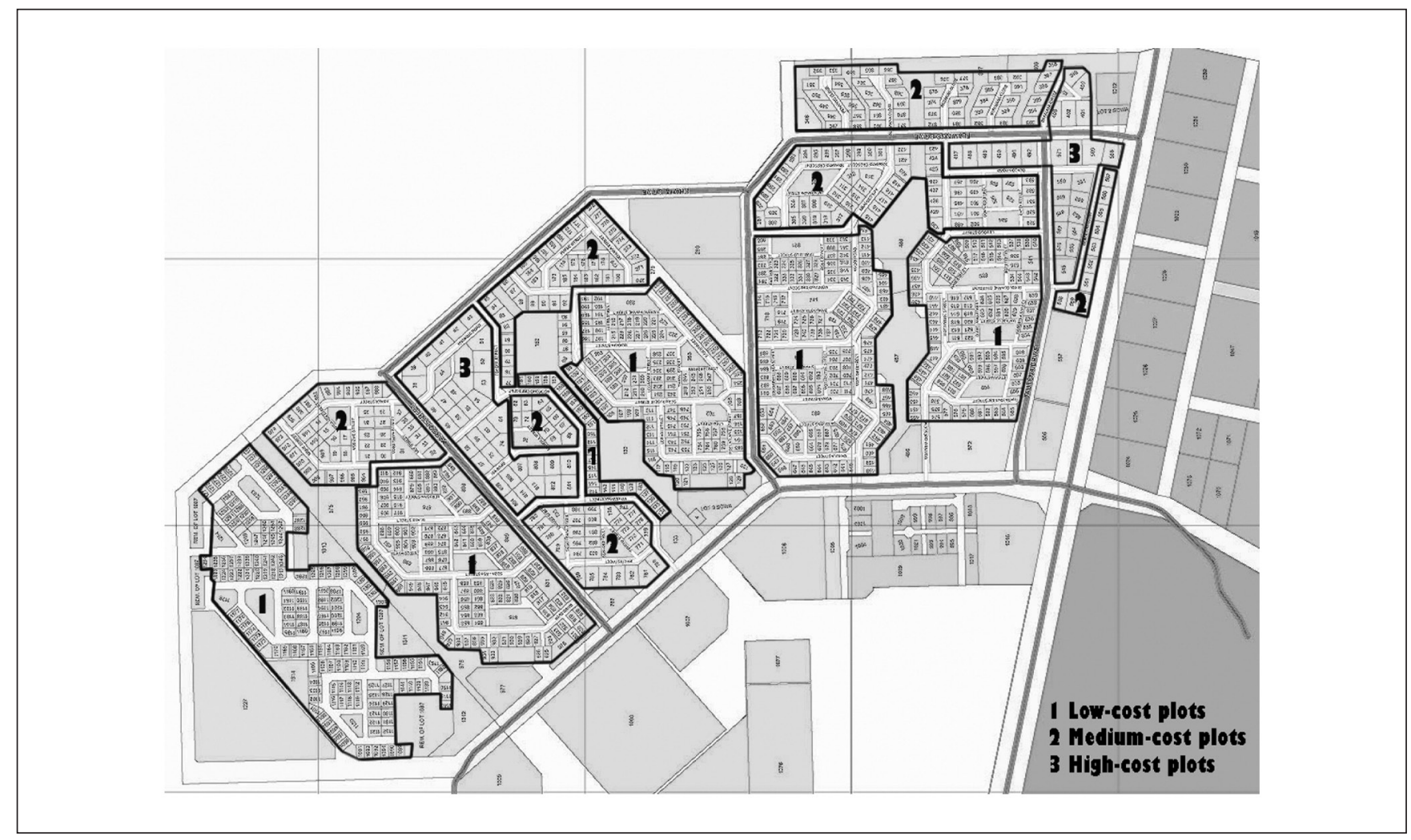

Figure 4. Map of Sowa showing low-, medium-, and high-cost plots Source: Department of Surveys and mapping, Gaborone

wards, or even only a single ward (Schapera 1984, 23). This layout is typical in Tswana built environments.

\section{Sowa Town}

Sowa, which is located $163 \mathrm{~km}$ to the north-west of Francistown, Botswana's second largest city, was built in 1991 (some literature suggests that Sowa was used only as a camp for workers between 1991 and 1993). The population is estimated to be three thousand, settling one thousand plots (Database at Sowa Town Council 2003). Most of the inhabitants are employed either by the Soda Ash Mine Company or the Sowa Township Authority. Figure 4 shows the current built environment of Sowa, including different plots sizes related to the cost and standard of the housing units built on them. The plots are categorized into those of low, medium, and high costs. Figure 5 shows a building design that is common across the three plot categories. There are also a number of commercial and industrial plots. Both public (local and central government departments) and private entities (Botswana Power Corporation, Water Utilities, the Botswana Housing Company, and Botswana Ash Mine) share the management of the township. The original area of Sowa was rebuilt and settled by new residents coming from different regions of Botswana.

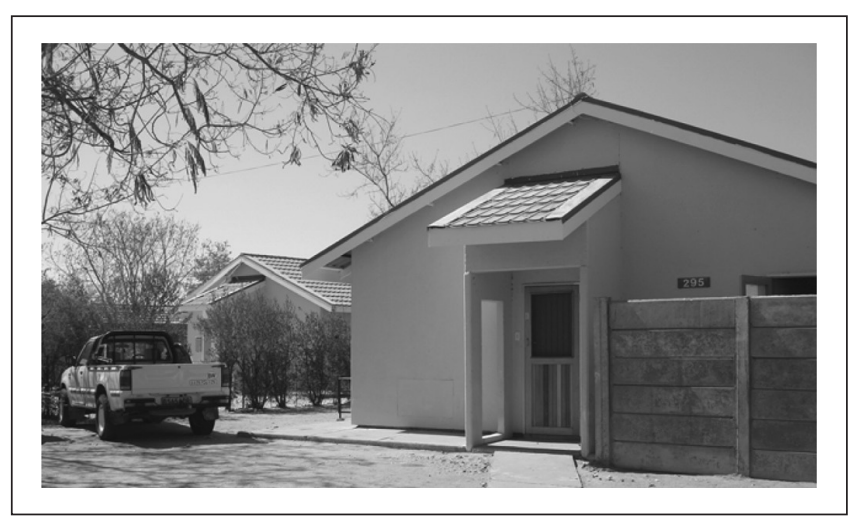

Figure 5. Common modern housing design on plots of all costs in Sowa town Source: Author

\section{Field Research}

In Shoshong, the author and two local experts in qualitative surveys started the field work by introducing the study at a preorganized public meeting held in the village kgotla with residents, officials, politicians, and the chief. This meeting aimed to introduce the study and prepare people for interviews, which were a central source of data. A number of 
Table I. Types of Interviewees Who Provided Data on the Planning System and Contexts of Sowa and Shoshong

\begin{tabular}{|c|c|c|c|c|c|}
\hline & Residents & Officials & Politicians & Academics & Planners \\
\hline \multicolumn{6}{|l|}{ Planning system } \\
\hline Semistructured interviews & $0^{\mathrm{a}}$ & 5 & 3 & 3 & 2 \\
\hline \multicolumn{6}{|l|}{ Shoshong } \\
\hline Unstructured interviews & 19 & 0 & 2 & 0 & 0 \\
\hline Semistructured interviews & 37 & 3 & 0 & 1 & I \\
\hline \multicolumn{6}{|l|}{ Sowa } \\
\hline Unstructured interviews & 20 & 0 & 1 & 0 & 0 \\
\hline Semistructured interviews & 40 & 6 & 0 & 0 & 0 \\
\hline
\end{tabular}

Note: Semistructured interviews conducted based on themes, whereas unstructured ones conducted in a story-telling mode.

${ }^{a} \mathrm{Few}$ were aware of the spatial and other relevant legislation.

wards were selected by the chief (kgosi) to represent the three tribes of the village. Each ward comprises eight to fourteen households. Because of the limited time available, priority was given to those households that were active in the community and that associated Tswana culture with their way of life. These included people who had lived longest in the village, were politically active, inhabited traditional Tswana huts, or ran a business from home.

As shown in Table 1, the survey included twenty-one unstructured and forty-two semistructured interviews. The conversation in the former took a story-telling mode, which most interviewees seemed to feel comfortable with. The latter was structured around particular themes relating to daily life practices, cultural meanings, recent changes in lifestyle, and local rules for cultural conservation and planning.

All interviews with people started with general conversation. Care was taken when asking questions of a personal nature. Direct observations of Shoshong's cultural environment were also used as a supporting method. They concerned the relations between people and with their living space, the uses of particular places in Shoshong, and the basis on which people distinguish one place from another. The researchers discussed all observations among themselves on a daily basis.

The findings from Shoshong were used to design the study in Sowa. The field work in Sowa was initially scheduled to coincide with a kgotla meeting, but the meeting was cancelled for unknown reasons. After interviewing the kgosi, he introduced the researchers in this study to a number of wards. The interviewees were selected to represent residents of the low-, medium-, and high-cost plots, in addition to centralized wards with public spaces, similar to those in Shoshong. Most interviews were conducted in the evenings and at weekends because residents work during the day, unlike in Shoshong where the majority are elderly or unemployed. About twenty-one unstructured and forty-six semistructured interviews were conducted in Sowa with people, officials, and politicians (see Table 1).

After the field research in Shoshong and Sowa, other populous Tswana villages, such as Mochudi, Tlokweng, Kanye, and Mughudesane were visited for a general comparison. The data collected were used to make in-depth analyses of the Town and Country Planning Act (DTRP 1977) and a general review of the Tribal Land Act (1969, revised in 1989), the Development Control Code, the Building Control Act (1981), the National Policy on Culture (2001), and the Botswana Long Term Vision 2016 (Botswana Government 1997). These analyses examined the local values that these documents highlight, as well as how these values are considered and institutionalized in and by actors, policies, and strategies. The study eventually concentrated on the Town and Country Planning Act, because of its effects on policy and development plans, and because it is currently under review. A further thirteen semistructured interviews were conducted with officials, politicians, academics, and professionals who are involved in, or aware of, this review (see Table 1). The interviewees and the aforementioned planning documents were selected through discussions with representatives from the University of Botswana and the National Museum.

\section{Culture and Planning in Botswana}

Since 1976, the planning system in Botswana has been in continuous transformation from a purely centralized topdown model to one with bottom-up elements. The government aimed to build a system of district planning based on local consultations (Kalabamu 2006; Adams 2003; Noppen 1982). Consequently, the functions of four main central institutions - the District Administration, the Tribal Administration, the District and Town Councils, and the Land Board-have been devolved to community, district, and central government levels. In spite of these structural changes, the system of urban planning and development remains centralized around the Ministry of Land and Housing. The situation is even worse for the management of Botswana's cultural heritage. According to Keitumetse (2007), it is centrally implemented by separate government departments using uncoordinated tools, such as the Botswana Tourism Policy, the Botswana Conservation Policy, the National Conservation Strategy, the Monuments and Relics Act, and the National Policy on Culture. These tools define 
culture poorly. This can be partly traced back to the colonial period, the "Bechuanaland Protectorate" (1890-1966), when the British enforced new administrative, judicial, and economic policies, as well as new settlement patterns, that had profound effects on people's daily lives and planning law (Kalabamu 2006; Mbembe 2001). Some powerful tribes opposed such changes. Their authority, supported by influx controls enforced by the colonial power to restrict the mobility and migration of black Africans to urban centers or large villages, allowed them to maintain traditional social structures and the chieftaincy system, at least at the tribe level. Botswana was therefore governed by a double structure: the British protectorate and the chieftaincy (Kalabamu 2006; Campbell and Tlou 1984). Following independence in 1966, the newly elected government retained the British planning system as the quickest way of responding to extreme poverty, lack of human and material resources, and the expectations of its citizens. It overlooked the chieftaincy, and the double structure remained.

The double governing structure resulted in two main problems for development and planning. First, the various policies and legislation were neither legally nor institutionally streamlined. For example, there is a distinct division between the Town and Country Planning Act (DTRP 1976), implemented by the Department of Town and Regional Planning, and the Tribal Land Act (1969, revised in 1989) implemented by the Department of Land Boards. The Tribal Land Act generally gives greater respect to the domestic way of life, whereas the Town and Country Planning Act employs "Western" values of house designs, plot arrangement, and hierarchies between private and public spaces. When Tlokweng and other villages were included in the Greater Master Plan of Gaborone (the capital of Botswana), the inhabitants had to adapt to the new, Westernized standards of living enforced by the Town and Country Planning Act.

Many residents could not afford to adapt to the enforced standards and therefore moved to other areas where the local way of life is respected. (Anonymous 1, Botswana National Museum, July 2007)

Second, the planning system was established with little attention paid to the cultural context of Botswana. For example, the draft revision of the Town and Country Planning Act (2008, section 29) still defines "culture" with a short list of monuments and archaeological sites. Intangible and locally perceived values are not yet considered. It is true that before permission is granted to any development plan, an environmental and archaeological impact assessment must be carried out (Keitumetse 2009, 226). However, as the archaeologist Peoentle Jan put it,

Since government interests are mainly in archaeology ... most cultural heritage assessments are conducted through cliché and sometimes without any site visit. (interview, July 2007)

This was also confirmed by one consultant involved in the review of the Town and Country Planning Act "Cultural heritage is still not a priority for Department of Town and Regional Planning" (August 2007).

This is understandable because most urban policies and regulations, especially the National Policy on Culture (2001), the Development Control Code (1995), the Building Control Act (1981) and Wildlife Conservation Regulations (2001), include no critical consideration of local values or ways of life. For example, the Development Control Code was initially designed by a foreign planner around ideas of relaxed capacity and enabling strategy. The aim was to favor the impoverished by relaxing building restrictions to maximize the use of the limited area within plot boundaries. According to Bourennane (2007), people were not informed about this code and it was poorly implemented. However, the field research showed that most official planners seem not to understand the code and therefore do not implement it. As the physical planner for Sowa said, "the code is not centrally enforced because we do not know how to implement it" (interview, July 2007). Apparently, the planners do not understand it because its contents are not based on the local context of Botswana. They are solely taken from conventional planning models.

A worrying fact is the ignorance of local values in Botswana's "Long Term Vision 2016," a guidance document for future national development. This policy document pays little attention to quality of life beyond the provision of basic infrastructure such as water, electricity, and drainage. This, combined with the above findings, indicates that the current planning system may overlook "the local cultural uniqueness" (Mbembe 2002, 243) and threaten the rich cultural landscape of the different villages and towns. As a fory-two-year-old female resident in Tlokweng said,

It is becoming difficult to identify ourselves as Africans, because current development is characterized by Western houses, streets and shopping malls. (September 2007)

Such threats are locally recognized and supported by a growing consensus among the public, professionals, and official planners that there is a conflict between the planned Western-informed urban structure and Tswana culture. The challenge remains in finding a suitable means to promote modernization that is rooted in Tswana culture.

\section{Exploring the Cultural Landscape of Shoshong}

The empirical study of Shoshong revealed a rich cultural landscape, exemplified by concepts of person (self), group, 
lifestyle, spatiality, contracts, and conflicts. For analytical purposes, this landscape was grouped into three forms of values: the social, the spatial, and the political.

\section{The Social Form: People-People Relations}

I will live here as long as the relations with my neighbors are good. . . . My neighbors take care of me if I am ill and welcome me when visiting. (A fifty-fouryear-old female resident, June 2007)

Although the daily life practices in Tswana villages are traditionally conducted collectively (Larsson 1996), the reality today reveals different patterns. About 60 percent of the interviewees claimed that family ties and economic and political interdependencies, within each ward and across the nucleated settlements, bind people together. The remaining 40 percent regarded such relationships as something from the past. When rapid urbanization got underway many people moved from villages to urban centers, while new residents (impoverished domestic and regional immigrants) filled the vacuum left in the villages. Most wards populated with new residents are likely to have weak bonds of trust and socioeconomic ties. However, values of social coexistence seemed to function where the headman was still powerful. For example, the residents of Phaleng ward, from the Baphaleng tribe, considered socioeconomic interdependences and their own relations to the kgosi as a resource for social vitality. One elderly female said,

Living together gives us a feeling of security. I can easily borrow sugar from my neighbor . . . this may never happen in Gaborone. (July 2007)

All interviewees in that ward (three females and two males) agreed with her. At the village level, thirty-one of fifty-six interviewees declared sociocultural relations to be a sign of quality of life; however, most of them were elderly (forty-eight to sixty-five years old). The young and middleaged often stated that social relations are a sort of tradition. This was supported by a group of five people (twenty-two to thirty-three years old) waiting for transport to Gaborone. For them, traditions are either a village lifestyle or no longer valid in cities.

One female said that "social relations are possible in Shoshong, not in Gaborone." Another female continued, "Even in Shoshong, life has changed and people care less about each other." One male maintained, "This is a natural change of lifestyle as people are no longer living in villages and are now mixed with other ethnic communities" (interview, June 2007).

Such a change in lifestyle is still not obvious among elderly people, especially those who have lived in Shoshong for a long time. They still value the role of Tswana culture (particularly their relation with kgotla kgosing) in their daily life. One interesting observation was how people generally used the pronoun "we" or addressed plurality.

We share everything together . . . at the kgotla or patlelo. We build huts together ... women build the mud walls and men put on the grass roof. (An elderly male, June 2007)

Tswana culture may involve people living together in forms of social organization, rather than simply cohabiting in a place. However, it may also be that increased poverty makes people interdependent, or that communal values (codependence, networks, and trust) are common characteristics of traditional communities. Indeed, there is a strong sense of community in Shoshong, underpinned by Tswana sociocultural relations and collective ways of life. However, this seems to be a fading aspect of Tswana culture. Today, there are some wards with "good" social ties hosting regular sociocultural and political events. Such ties seem to function as networks for constant consultations, sharing of food, health support, and the relay of news. This is facilitated by the diverse spatially integrated public domains devised for community life.

\section{The Spatial Form: People-Place Relations}

A group of five men sitting in one of the Bakaa tribe's wards maintained that a Tswana living environment operates through a network of social ties, with each tie having a corresponding physical place in the spatial structure (see also Larsson and Larsson 1984). For them, spatial elements such as kgotla (a shared open public space at the village level), patlelo (a shared open semi-public space at the ward level) or lolwapa (a shared open semi-private space within a plot) embrace different socioeconomic and political functions. These elements are locally perceived as nodes for networking cultural allegiances and political commitments. They communicate through a court hierarchy where people's daily concerns, conflicts, and disputes are resolved.

Such spatial system and hierarchy are overlooked in the new (west-south) areas of Shoshong. The Master Plan of Shoshong (2005) shows these areas modeled after a "Western" grid plan. The traditional Tswana spatial characteristics and fabric are undermined. In her analysis of traditional Tswana housing, Larsson (1996) explores not only the predominant relationships between everyday activities and the use of space, but also how the design of Tswana spaces is based on their actual uses and functions. Each plot links indoor and outdoor spaces through values of privacy, function, gender, and age. Outdoor spaces sometimes have greater significance; for example, people receive guests or sleep in the lolwapa (Figure 6).

The field research showed that Shoshong is currently undergoing rapid change in its general appearance and social structure. Today, the housing units are, as shown in Figures 3 


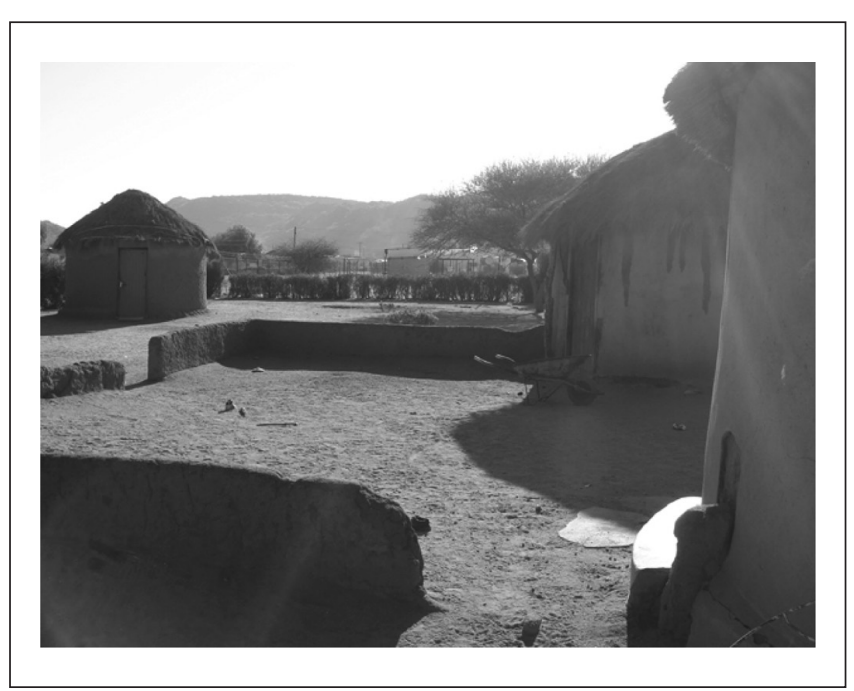

Figure 6. A lolwapa linking two hut, used to receive guests or for family gathering Source: Author

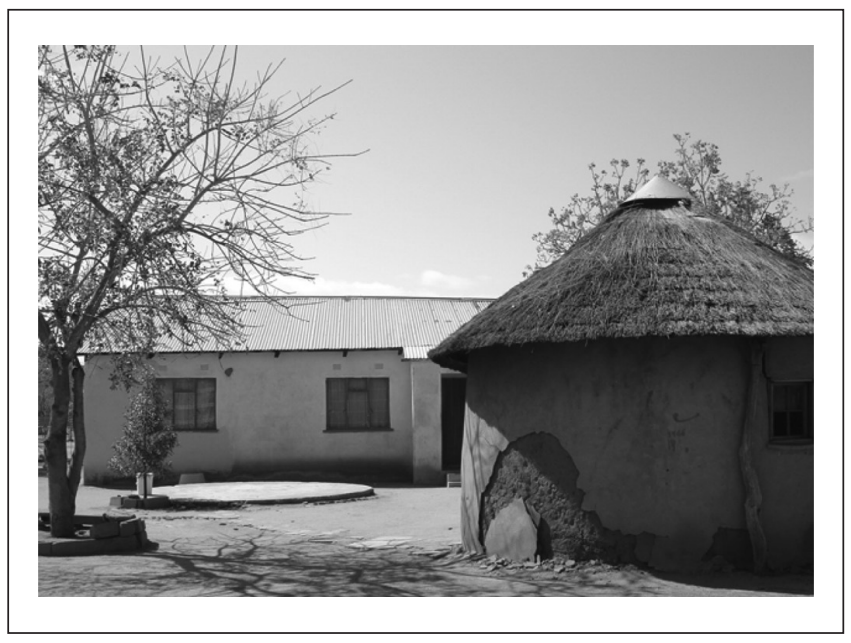

Figure 7. A "modern" house has replaced a Tswana hut, its foundation still visible on the ground Source: Author

and 7 , increasingly being replaced by modern rectangular houses built from corrugated metal sheets and bricks. Young and middle-aged people are migrating to urban centers even while maintaining their houses in Shoshong. They often later remodel the units into modern houses similar to those newly built in urban centers.

Although many people regard these changes as a symbol of modernity or prominence in the indigenous hierarchy, others find them uncomfortable. A couple living in a modern house in Phaleng ward said that modern houses are more affordable than huts, can be built in bigger sizes, and withstand the strong winds of winter. However, unlike Tswana huts, modern houses tend to be hot in the summer and cold in the winter.

\section{The Political Form: People-Authority Relations}

The rules of litigation in the politico-jural system are based on Tswana normative repertoire, known as mekgwa le malao ya Setswana (Tswana customs and law). Its principles of self-organization, local beliefs, and norms, seem to hold the societal organization of Shoshong together and shape the social practices. According to Schapera (1984; cited in Gulbrandsen 1996, 129), daily life concerns are debated through a hierarchy of kgotla courts. It is initially discussed in the domestic square of a plot. If unresolved, the case is brought into the public domain of the descent group court, from where it may be appealed through several court stages, ultimately reaching the royal court (kgotla kgosing) over which the kgosi or one of his deputies presides. Through such spatial and social interrelations everybody is closely linked with the politico-jural hierarchy headed by the kgosi. This sociopolitical network of power relations and cultural values is centered on the kgotla (as a public forum, social space, and court). One of the main functions of the kgotla is a mediation place for conflicts and disputes. However, kgotla kgosing does not function to resolve conflicts as much as maintain social harmony (kagiso) among the tribe (or village) members (Gulbrandsen 1996, 131). People also regard their attachment to kgotla kgosing as essential for establishing and maintaining their self-identity, in addition to being recognized as a rutegile, or a "learned person," and to identify with a community. In this way, the Tswana sociospatial relationships form constituent elements (and a platform) for the political system. As the kgosi of Shoshong said, "Kgotla meetings allow people . . . to express their opinions and negotiate their daily concerns" (June 2007).

After the kgotla meeting with the local community where this study was introduced, the head of Phaleng ward said that the kgosi had failed for several months to arrange this meeting. About ten of the twelve interviewees who did not attend the meeting asserted that there was no reason to attend meetings where people could not speak freely. During the kgotla meeting, it became obvious that people had gathered to be informed of decisions already made, rather than to speak and discuss their concerns. Bypassing the hierarchy of kgotla courts seems to have produced sociospatial "voids" according to which people's ties with the kgotla kgosing were weakened. The roles of, and relationships between, the ward headmen and village kgosi were also seen by the ten interviewees as having weak cultural representation. In a Mosinyi ward, a middleaged woman, who had gathered with a group of people discussing the limited community outreach of the local clinic (see Figure 8), was asked why she did not raise such issues with the village kgotla. She responded, "We usually discuss our concerns in the ward with our headman before raising them in the kgotla." But another woman added, "We are certain that our kgosi has no power to help" (June 2007).

According to an elderly man, when the government reduced the role of kgotla kgosing, people gradually became distanced from the kgosi and the Tswana way of life. He believed that 


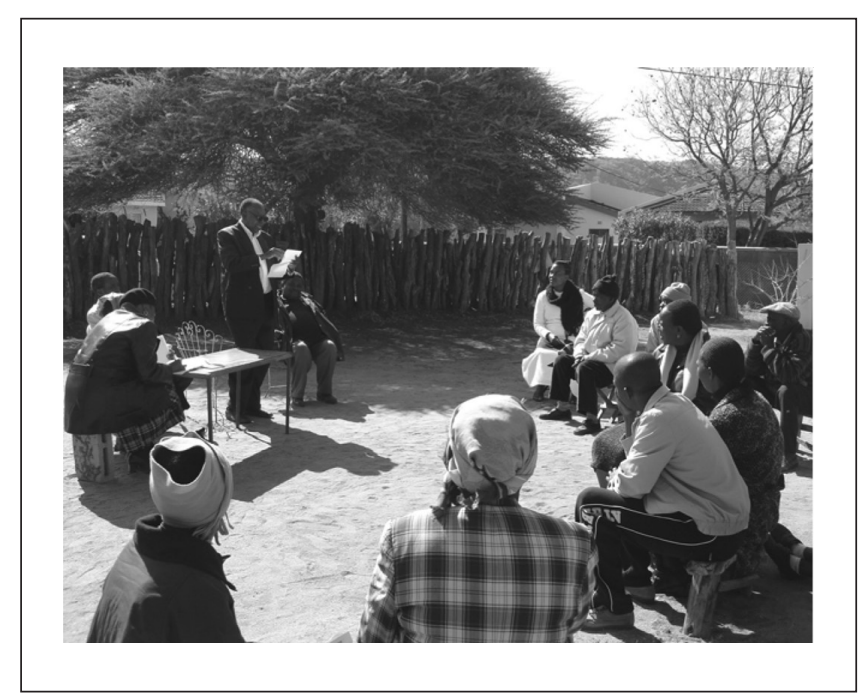

Figure 8. Inhabitants of a Mosinyi ward discuss the limited capacity of a clinic

Source: Author

most activities were no longer conducted collectively, nor enjoyed the advice of the kgosi. Other interviewees claimed that the kgosi did not represent them, because he was not locally elected and did not live in Shoshong. This issue of representation also was raised by some interviewees against the changed position of ward headmen into officially appointed officers. The head of Phaleng claimed that life had become too complex to be handled by the kgotla kgosing, and that traditional institutions of the chieftaincy could not tackle the complex, "modern" programs of today's global market and the current needs of Botswana. For him, present modes of governance conduct were more relevant to today's lifestyle and needs. During the field research, it was evident that there are variations of social practices in the different wards of Shoshong. This indicates ongoing sociopolitical transformations characterized by a shift away from the chieftaincy. This shift is distinct in the new areas of Shoshong where the development planning decisions are allocated to the Land Board. While the grid plan of these areas allows no physical platforms for kgotla meetings, the village council was founded in order to represent local concerns. From an institutional perspective, the council links the local community with the Land Board. However, overlooking the relationship between the social organization of Tswana culture, sociospatial interactions, and the kgotla kgosing seems to have adversely influenced the domestic social harmony, as well as the relationships between networks of social ties and spatial structure. It is also possible that marginalizing the chieftaincy from the governing system has hindered its development as an institution, thereby rendering it outdated and incapacitated. Generally, people are still keen on their traditional political system, as institutions, actors, processes, and practices. But its limited authority, its inability to deal with the complexities of the modern day, and its divergence from the official legal system causes them to avoid the kgosi kgosing.

Even though the cultural landscape of Shoshong can be categorized as above into three forms of values - the social, the spatial, and the political - these cannot be understood in isolation from each other; they are interwoven, overlapping in the different aspects of Tswana culture. These values may be in decline, eroded by the foreign characteristics of a "modern" way of life, enforced at the local level by the existing planning system. Yet these values seem to persist, at least, in people's memories and daily discourses. They represent Tswana idioms that are not just a part of the daily language but also a part of the culture.

\section{Examining the Cultural Landscape of Sowa}

When the findings of this study were presented at a seminar hosted by the National Museum of Botswana in August 2007, the participants (forty representatives of government departments, private sector, academia, and the local community) were dismayed to hear that the social, the spatial, and the political values barely functioned in Sowa. Some participants explained this failure as a consequence of the general lack of cultural studies and the narrow perception of the relationship between culture and development. Jan Wåreus, the town planner at the time of Sowa's planning in 1991, said in the seminar that "it was then a challenge to talk about culture. Cultural conservation was not a priority for the Department of Town and Regional Planning. Their response was always, 'traditions and culture are for villages not for towns ... we are modern now.' But our concern was to preserve Tswana culture." The 16-year period from construction in 1991 to our field research in 2007 has perhaps not been long enough to build a socially coherent community. But Sowa's planning and design should be examined critically, including the processes of cultural assessment, to determine if such a community is even possible.

\section{The Social Form}

In spite of the well-organized physical environment of Sowa, more than 70 percent of the people interviewed during this study said that Sowa had very few cultural and social attractions. They also found little reason to establish social relations in a place where, "they do not feel comfortable raising a family" (interview with a social worker, July 2007). These findings are unsurprising, as fifty-two of the sixty interviewed declared weak feelings of belonging and wished to move as soon as they secured another job. It also was observed during the field research that neighbors barely knew each other and that public spaces hosted few public gatherings or children playing. Some argued that Sowa Township Authority undertakes 


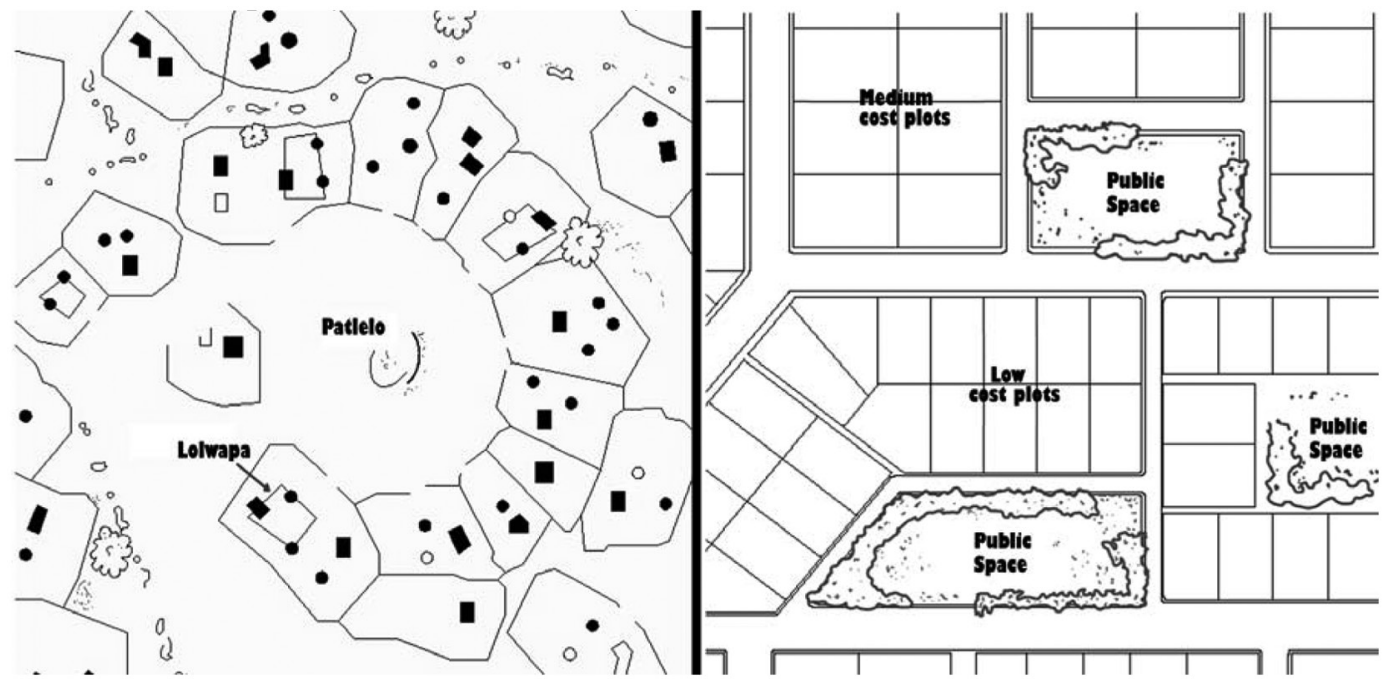

Figure 9. Comparison of a traditional Tswana village (left) and Sowa town (right)

Source: Developed by the author from Figures 2 and 4 of this article

development and runs community programs without engaging the public. Others showed no personal interest in taking part in any community activity.

Before 1991, the area was partly inhabited by the Basarwa, an indigenous group of hunter-gatherers related to the Khoisan. A social worker with the Sowa Township Authority responded when asked about those inhabitants,

The whole area was replaced by new development. . . . The Basarwa were forced to leave because their huts were demolished and the new living standards were unaffordable. (August 2007)

The planners had three weeks to outline detailed plans (interview with Wåreus, June 2007) leaving Sowa without critical considerations of its original built environment and the complexity of Tswana culture. Overlooking the latter may explain why all interviewees living in medium and lowcost plots (forty-six of sixty) affirmed that they felt uncomfortable with the building designs, the plot arrangements, the unaffordable living standards, the nontraditional lifestyle, and the limited plot sizes. One of them said,

The plot is tight . . . with no outdoor space to stay in or to receive people. It is hot inside these concrete houses ... our huts are suitable for hot weather . . . therefore we go to the village during the weekends. (A male resident, August 2007)

As a protest against this enforced way of life, some of the households on low- and medium-cost plots built temporary outdoor structures to use as kitchen, storage, or retail space. The Township Authority either forcibly removed such structures or fined the households. The building of these temporary structures is perhaps a common reaction among people moving from rural to urban areas where building standards are strictly regulated. According to Sowa's physical planner, people attempt to ignore the contextual differences between town and village. When asked if "enforced building regulations cause people to reject Sowa as a suitable place to live," he replied that "it is true that the Building Regulation Act ... and the Town and Country Planning Act have a limited capacity to address current problems . . . but these are the urban regulations" (interview, August 2007). Apparently, people never raised a protest against the strictly enforced way their housing units, plots, and wards, were designed and spatially arranged.

\section{The Spatial Form}

The planners were mainly concerned about representing two Tswana spatial ideas in the Sowa plan. First, the way Tswana homesteads are organized in a horse-shoe layout centered on a public space (Figure 9). Second, the traditional ratio of public space versus occupants - while in the past each person enjoyed $10 \mathrm{~m}^{2}$ of open public space (interview with Jan Wåreus, June 2007), current urban planning standards allocate $10 \mathrm{~m}^{2}$ to one household. Since the average household has five members, the public space available to each individual is much reduced.

Even though the planners succeeded in representing these two spatial ideas, most of the open public spaces did not function properly. Figure 10 shows a typical space-unclean, 


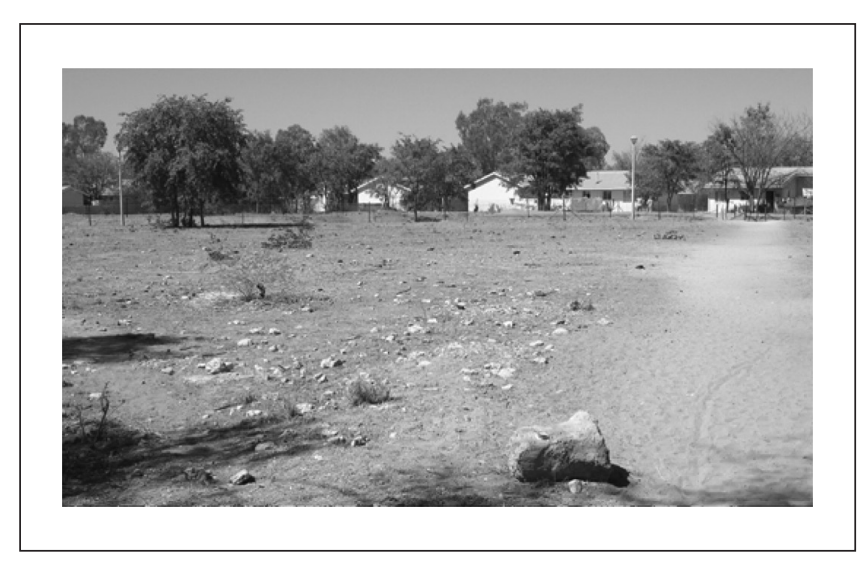

Figure 10. A common view for open public spaces in Sowa Source: Author

rarely used, and poorly accessed and arranged within the spatial fabric. This may be the result of the weak spatial connection with surrounding plots. In Shoshong, people must walk through open public spaces to access their plots, whereas the plots in Sowa are accessed directly from the streets. Issues of access are tightly connected with people's practices in daily life, as well as the way they move across the hierarchy of spaces from indoor (private) to outdoor (public). In relation to space hierarchy and design, the horseshoe layout facilitates "eye-connection" between parents from their plots to children playing in the patlelo. The husband of a couple in a medium-cost plot commented, "Although our plot surrounds this open space, we do not allow our children play there because it is not clean, not very open, not directly connected to our plot, and we cannot see them while they are playing." His wife wondered why they [township authorities] keep such places if they do not take care of them (interview, July 2007).

Other space-related values like privacy, gender, and age were essentially undermined. The positioning of the kgotla also failed to strengthen Tswana social-spatial-political relations. It was built with little attention to its genuine function, historical development, or to its relations to the people and the spatial fabric. For example, its location does not provide people with easy and equitable access. The physical planner explained that the kgotla was built on one empty plot in the later stages of development. The lack of spatial integrity in Sowa cannot be isolated from the undermined social form. The field research showed that Tswana sociospatial relationships, which are horizontally linked between wards and vertically across the hierarchy of kgotla courts, were not evident in Sowa.

\section{The Political Form}

While the planners succeeded in integrating the principal elements of kgotla kgosing (kgotla, and wards with open public spaces) in the Sowa plan, its role remained advisory if not superficial. Overlooking Tswana custom (mekgawa le melao ya Setswana) as well as the political dimension of the sociospatial hierarchy of kgotla courts has hindered the development of a kgotla kgosing with a functioning sociopolitical organization. In addition, Sowa's kgosi was appointed by the government, with limited political authority to make decisions, and this has detached him from his role as a cultural representative in the eyes of the residents. A thirtyeight-year-old female resident of a high-cost plot said,

We do not trust the kgosi . . because we did not elect him. Kgotla meetings are not interesting because the kgosi cannot give promises. (Interview, July 2007)

Locally, the kgosi is expected to represent tribal customs and practices in governing as well as in his daily life (Denbow and Thebe 2006, 22). The residents were not only critical of the superficial role of kgotla kgosing but also criticized the enforced modern law - the institutions, rules, regulations, and sentences - because of its limited sensitivity to Tswana values and way of life. An economist working for the Township Authority took this further, saying that "those in charge do not understand current law because it is different from our culture. It is true that culture and law change with time . . . and apparently we haven't yet been able to adapt to modern law" (August 2007). Those in charge of enforcing the law in Sowa did not understand it because they could not reconcile its meanings to their cultural values, norms, commonsense knowledge, and experiences. This may explain the unclear divisions of responsibilities, authorities, and powers between the Township Authority and kgotla kgosing.

This, combined with the missing social ties and Tswanabased spatial structure in Sowa, has adversely influenced the political environment of Sowa. People seem to have lost trust and interest in the governing system. In addition, fifty-eight of sixty interviewees showed little interest in their relationship with kgotla kgosing or knowing about the concerns of the local community. One worrying indication is the increasingly passive attitude among the residents toward community development, as well as the benefits they miss by belonging to some form of social organization. Although within Tswana culture, the kgotla serves the development of socially coherent and progressive communities, the kgotla of Sowa seems to have been built for the purpose of obtaining the consent of the general public and maintaining the legitimacy of the Township Authority. These findings indicate a limited possibility for the emergence, at least in the near future, of a self-organizing community, or of a political system grounded in Tswana values and integrated with the planning system. Today, Sowa is governed through a managerial system with a top-down approach, which has not only "turned off" large numbers of people to the political process, but also has led to elitist policies that have benefited only a few.

In addition, the field research uncovered two more reasons for the failure to account for culture in the planning for 
Sowa. First, the Tswana cultural landscape was analyzed and interpreted without communicating conflicting views of the various stakeholders. These included the town planners (and architects, quantity and land surveyors, and so on), who were interested in "facilitating Botswana's traditional cultural activities and social interaction in the Sowa plan" (interview with Jan Wåreus, June 2007); the Department of Town and Regional Planning and Botswana Housing Company (which lead the Sowa project), which agreed to "culturize" the development plan as long as "modernity" was secured and the implementation processes were not delayed; Soda Ash Mine Company of Botswana, ${ }^{2}$ which was involved in the entire process in order to house its miners and employees; Swedeplan, the international division of the Swedish National Housing Board (Boverket), which was interested in the transfer of urban planning techniques as part of a Swedish assistance program to Botswana (Swedeplan and DTRP 1997); the current residents, who were interested in inhabiting a modern urban space but also in continuing their traditions; and the aboriginal people, the Basarwa, who wanted to remain in the area of Sowa. Eventually the planners' views and knowledge were allowed to steer the planning process with a discipline-led approach, backed by the top-down authority of the Department of Town and Regional Planning and Soda Ash. While the process was therefore left without any real cultural study, the planners assumed that people would appreciate their initiative to "save" Tswana culture.

Second, the planners assumed that replicating traditional spatial elements could facilitate traditional cultural expressions, in an urban area designed and planned to serve the mining industry. But people live in Sowa for employment, rather than for a sense of community. This has hindered the development of any social space as an outcome of sociocultural processes that include diverse types of interactions among people and with the built environment of such space. Another issue is that Tswana living environments are traditionally developed through the cultural agency of tribal families, whose social knots form the basis for spatial organization and cultural coherence. In sum, Sowa is a unique case study on how planning failed to consider local knowledge and the sociocultural context.

\section{Cultural Institutionalization for Change and Continuity}

The empirical findings from Sowa and Shoshong provoke important questions. Why does culture matter in urban development? What affects material outcomes and quality of life? How can urban planning be rooted in culture so that urban change ensures cultural continuity?

Since the planners of Sowa saw preserving culture as an objective, rather than as integral to the process, the Tswana cultural landscape was incorporated with the planning for culture approach, but through a centralized top-down process of cultural assessment and interpretation. In this, culture was perceived as a "thing" rather than, as Williams $(1958,1966)$ puts it, a "lived experience." The planners used a few spatial elements (passages, public spaces, horse-shoe layouts, and the kgotla) to represent Tswana culture, but uprooted from their sociocultural context. On the other hand, the empirical study of Shoshong showed that the meaning of Tswana is embedded in discursive relations, which are constructed not only among people but also with their built environment. Three interlinked cultural forms (the social, the spatial, and the political) characterize these meanings and frame people's way of life. These forms could not be unfolded and represented in the three weeks allotted during Sowa's initial planning stage, dominated by the role and "scientific" knowledge of the planners. In this way, their approach ignored the communal basis of planning for culture, which is shaped by decentralized bottomup approaches, and ignored the cross-sectorial basis of integrated conservation, which is shaped by decentralized top-down approaches. Therefore, a distinct gap of interaction emerged in their approach between the planners and both the local community and other experts. While the planners' initiative of integrating culture in planning was then a challenge, Sowa failed to function culturally. In response, this article suggests a shift toward cultural institutionalization.

Explaining what cultural institutionalization means exactly requires breaking down planning into processes (rules, structure, powers, actors, relations) and outputs (actions and development plans), with the former producing the latter. Cultural institutionalization suggests that the processes of contextladen cultural conception and the utilization of actors and interests become integrated in urban planning, and requires that these processes expand beyond official institutions and the boundaries of scientific knowledge, even if these are presented as being open to local sociocultural contexts. It is important to highlight here that "institutionalization" neither refers to a narrow formalization of cultural consideration in planning nor to "building in" new participatory decision-making processes that become, for all stakeholders, the normal "way of doing things." The fact that Botswana inherited the British planning system after independence indicates an entrenched problem of cultural insensitivity in planning across the various levels of influence. For this reason, it is vital to discuss the way culture ought to be integrated in cultural institutionalization at not only the local but also district and national levels.

Cultural institutionalization requires that conservation planning processes become intrinsic at the local level. Cultural conception and utilization are carried out from within the native environment of the case at stake, and lead by critical reflections on the sociocultural relationships among the different local social groups as well as between those groups and their built environments. The role of planners is important in unfolding the specific characteristics of each case and in generating legitimate practices and the representation of local culture during the entire process of space making. Sowa showed how the planners failed to unfold the sociocultural context of Tswana spatial fabric. For example, 
overlooking the cultural characteristics of the kgotla has adversely influenced its capacity for facilitating social harmony (kagiso) in the local community and forming an integral part of the domestic political system. It is used today as a platform for announcing decisions, in contrast to its traditional role in forming decisions. In this context, cultural institutionalization suggests rethinking the value of kgotla kgosing as a social, spatial, and political system where the Tswana politico-jural hierarchy becomes reinstitutionalized in policy discourses and documents instead of being marginalized and replaced by "modern" governing systems.

Moreover, cultural institutionalization is not a case-bound approach. It requires situating each case in its wider social context and planning system. In practice, this means expanding the processes of development planning decisions to allow a wider range of stakeholders, views, and values to interact, bypassing the current rigid divisions of power, authority, and position across vertical and horizontal hierarchies. Between the local and national levels lay ten district and four town councils, with the executive authority in each vested in a district commissioner appointed by the central government. The commissioner is assisted by a district council and a district development committee, which are partly appointed and partly elected. Each of these institutions works as an independent entity and holds few obligations for integrating culture. While this is often explained by their limited human and financial resources, their actual role in culture and planning has rarely been deliberated. One suggestion may be to empower the four main district institutions - the District and Town Council, the District Administration, the Tribal Administration, and the Land Board-along the vertical hierarchy of the planning system. This could change their role from that of watchdogs for national programs into moderators of conservation planning along local lines of culture, with rules enforced nationally.

The extent to which culture can be institutionalized in the planning process without challenging legislation related to the spatial and other relevant areas remains a critical question. Culture is not a development priority in Botswana, given the narrow focus on archaeology and tourism. The Town and Country Planning and Tribal Land Acts are also in distinct conflict over enforcing living standards, building regulations, and way of life. This was evident in the dramatic sociocultural changes seen in the villages within the boundaries of the Greater Gaborone plan. It is expected that any proposed adjustment on the national planning system would challenge the current sectorial mechanisms of urban planning and heritage management. Resistance may arise if such adjustment is based on an even redistribution of power and authority among the top-, middle-, and bottom-level actors or if the role of local communities is changed from being audience into interactive actor. However, it is perhaps possible to equate all actors in terms of position. For example, one can critically rethink the positions, roles, and powers of the kgotla kgosing in relation to the Ministry of Local
Government (1996), the Ministry of Lands and Housing, and the House of Chiefs (an advisory body to the Parliament with no legislative power, concerned with government decisions affecting the tribal organization and property and customary law), in addition to the role of the development committees at the district and town or village levels.

\section{Concluding Comments}

This paper has focused on the practical aspects of both the conception and utilization of culture in the making of development planning decisions, building on works that recognize culture as neither static nor an object (Gibson and Pendlebury 2009; Young 2008; Williams 1966). A distinct communication gap exists between planners (and planning practitioners) and the local communities in most existing urban planning paradigms, exemplified by the dominance of the planner over stakeholder interactions. While the complexity of this problem cannot be denied, newly emerging democratic models of planning still elevate some players over others, albeit with greater legitimacy than before. The dominant interests involve other stakeholders to dictate rather than integrate, and in this way attempt to democratize the planning process.

This gap seems larger in postcolonial societies because of the legacy of domination, not only on their peoples - their language, traditions, ways of life, cultural identity, and developmental resources - but also the functions and shape of their governing systems (Mbembe 2001, 2002). In Botswana, the effects of colonialism have persisted after independence. Most international assistance programs have implemented societal development, with little consideration of local contexts; this is evident in the different villages and urban centers. In Shoshong, a Western city image and lifestyle are rapidly replacing the three forms of local values. Sowa is a unique example of how foreign experts and conventional knowledge were directly used in the production of a modern town with only an abstract representation of Tswana culture. It represents an art-cultural space produced (or repeated) from a Westernized system of meanings and values. The fact that Sowa is a geographically isolated mining town, with limited socioeconomic activity, partly explains the failure of its cultural functions. However, it is the centralized top-down approach of planning for culture, in which the planners' scientific knowledge and foreign expertise were the main inputs, that has resulted in the kind of town that can be found everywhere in the "modern" world. Its built environment reflects the repetitive gestures of instruments designed in, and for, a foreign context, and this includes the governing systems and the conduct of life as well as the physical material and design of the urban fabric and its buildings. The sociocultural relationships between residents uncovered in Shoshong were overlooked in Sowa. This has adversely influenced the hierarchy of Tswana politico-jural bodies and institutions, in addition to the possibility of constructing living spaces capable of sustaining collective living patterns. 
The conception and utilization of culture should become integrated in the entire process of planning. The cultural characteristics of each planning case must be situated in their broader social context, and the institutional hierarchy of the planning system adjusted to allow for a wider range of stakeholders interactions, regardless of current divisions in authority, power, and position. The ongoing review of the Botswana planning system is a valuable opportunity for cultural institutionalization. This inclusive approach may maximize the potential of Tswana culture in urban policies. Culture has always been a neglected dimension in development, and change requires a sense of urgency.

\section{Appendix}

\section{Personal Communications}

Alphones, Thomas. 2007. Kgosi (Chief) of Sowa Town.

Ambaila, Odirile. 2007. Social Officer, Social Welfare and Community Development, Sowa Township Authority.

Chephete, Ralph. 2007. Director of Department of Town and Regional Planning.

Ethasetse, Tlale. 2007. Headman of Phaleng Ward, Shoshong.

Fabian, Ntfaga. 2007. Village Kgosi (Chief), Shoshong.

Gagoepe, Gape Mosinyi. 2007. Headman of Mosinyi Tribe, Shoshong.

Khudu, D. 2007. Director of the Department of Town and Regional Planning, Ministry of Lands and Housing, Regional Office, Francistown.

Matlapeng, Geoffry. 2007. Senior Curator Archaeology, Salvage Unit, National Museum of Botswana.

Mabaila, Odirile. 2007. Physical Planner, Sowa Township Authority.

Mojalemotho, Rudolph. 2007. Deputy Director, National Museum of Botswana, Gaborone.

Molethi, Mphoyakgosi. 2007. Councillor, Shoshong.

Mopati, John Molosiwa. 2007. Assistant of Mosinyi Headman, Machailo Ward, Shoshong.

Mosha, Aloysus. 2007. Associate Professor in the Department of Architecture and Planning, Botswana University. E-mail:moshaac@mopipi.ub.bw.

Mositlaphala, Khumoyame Mosetlhe. 2007. Kgotla Wiseman, Mosinyi Tribe, Shoshong.

Oitsele, 2007. Director of Shoshong Land Board.

Peoentle, Jan. 2007. Private Archaeologist, Gaborone.

Tsheboeng, Alfred. 2007. Private Archaeologist, Environmental Impact Assessment Company.

Wåreus, Jan. 2007. Private Consultant on Town Planning. The town planner for Sowa Development Plan at DTRP.

Anonymous 1. 2007. Archaeologist, National Museum of Botswana.

\section{Acknowledgment}

The author would like to thank Lars Orrskog for his continuous support and constructive comments during the conduct of this study. Aloysius Mosha and Susan Keitumetse at the University of Botswana, Nils Viking at the Royal Institute of Technology, and Jan Wåreus, private consultant on town planning and the town planner for the Sowa Development Plan were instrumental during the field research. Conducting the field works wouldn't have been possible without the significant assistance of Ms Lesedi Rantwa and Ms Obakeng Leswena. Thanks to the three anonymous reviewers and the editors of this journal whose critiques significantly strengthened this article. Special thanks go to Nassir Isaf for his diligent copyediting. Finally, the copyright permissions granted by the Department of Surveys and Mapping, Ministry of Lands and Housing, Botswana, for the publication of maps of Sowa, Shoshong, and Botswana, and by Annita Larsson and Viera Larsson for the publication of the drawing of spatial arrangement at a plot level are gratefully acknowledged.

\section{Declaration of Conflicting Interests}

The author(s) declared no potential conflicts of interest with respect to the research, authorship, and/or publication of this article.

\section{Funding}

The author(s) disclosed receipt of the following financial support for the research, authorship, and/or publication of this article: The author received financial support for the conduct of this study from the Swedish International Development Cooperation Agency (Sida).

\section{Notes}

1. No intention here to polarise the two approaches. They are highlighted to explain how culture is often approached in planning models and to ease the analysis of the research problem carried out in this study.

2. A corporation formed by the Government of Botswana, De Beer (Family of Companies that dominate diamond exploring, mining, and trading), and the African Explosives and Chemical Industries (AECI).

\section{References}

Adams, M. 2003. Land tenure policy and practice in Botswana: Governance lessons for Southern Africa. Austrian Journal of Development Studies 19 (1): 55-74.

Arizpe, L. 1997. Conviviability: The role of civil society in development. Global Aid 3: 1997-98.

Baeker, G., and D. Cardinal. 2001. Beyond garrets and silos: Bringing communities together through cultural planning. http://www. cultureandcommunities.ca (accessed November 10, 2007).

Bianchini, F., and L. Ghilardi. 1997. Culture and neighbourhoods. A comparative report. Strasbourg: Council of Europe.

Botswana Government. 1997. Botswana long term vision 2016. Gaborone, Botswana: Government Printers.

Bourennane, M. 2007. A legal framework for enabling low-income housing: A study of women's access to home based enterprises in Botswana. Stockholm: KTH University, USAB.

Campbell, A., and T. Tlou. 1984. History of Botswana. Gaborone, Botswana: Macmillan. 
Council of Europe. 1975a. The Declaration of Amsterdam. http:// www.icomos.org/docs/amsterdam.html (accessed March 21, 2007).

Council of Europe. 1975b. European charter of the architectural heritage. http://www.icomos.org/docs/euroch_e.html (accessed April 15, 2007).

Denbow, J., and P. Thebe. 2006. Culture and customs of Botswana. Westport, CT: Greenwood

Department of Town and Regional Planning (DTRP). 1977. Town and Country Planning Act. DTRP, Botswana.

Dreeszen, C. 1997. Community cultural planning handbook: A guide for community leaders. Boston, MA: Americans for the Arts and the Arts Extension Service, University of Massachusetts.

Engelbrektsson, N., and J. Rosvall. 2003. Integrated conservation and environmental challenge: Reflections on the Swedish case of habitat. In The human sustainable city: Challenges and perspectives from the habitat agenda, edited by F. L. Girard, B. Forte, and M. Cerreta, 429-56. London: Ashgate.

Gibson, L., and J. Pendlebury. 2009. Valuing historic environments. London: Ashgate.

Gulbrandsen, Ø. 1996. Living in their Lives Court: The counter-hegemonic force of the Tswana kgotla in a colonial context. In Inside and outside the law, edited by O. Harris. London: Routledge.

Hyden, G., J. Court, and K. Mease. 2004. Making sense of governance: Empirical evidence from 16 developing countries. Boulder, CO: Lynne Rienner.

Jokilehto, J. 2004. Sustainability and integrated urban heritage management. In Sustainable Urban Heritage Management. A conference report. Vilnius, 22-24 April.

Kalabamu, F. 2006. The limitation of state regulations of land delivery processes in Gaborone, Botswana. Interdisciplinary Design and Research 28: 2.

Kalabamu, F., and B. Thebe. 2005. Effects of urbanisation and changes in technology on traditional settlements in Botswana: The case of Kanye Village. Botswana Journal of Technology 14: 1.

Keitumetse, S. O. 2005. Living and archaeological sites in Botswana: Values and perception in cultural heritage management. Pula: Botswana Journal of African Studies 19 (1): 37-47.

Keitumetse, S. O. 2007. The cultural implications of a CBNRM1 programme for community tourism development in Botswana. Conference paper on Heritage and Environment, June, Glasgow.

Keitumetse, S. O. 2009. The eco-tourism of cultural heritage management (ECT-CHM): Linking heritage and 'environment' in the Okavango Delta regions of Botswana. International Journal of Heritage Studies 15: 223-44.

Larsson, A., and Larsson, V. 1984. Traditional Tswana housing. Botswana Notes and Records 17: 37-45.

Larsson, A. 1996. Modernisation of traditional Tswana housing. Lund, Sweden: KF-Sigma.

Mason, R. 2002. Assessing values in conservation planning: Methodological issues and choices. www.getty.edu/.../pdf_ publications/assessing.pdf (accessed May 10, 2008)

Mbembe, A. 2001. On the Postcolony. Berkeley: University of California Press.

Mbembe, A. 2002. African modes of self-writing. Public Culture 14 (1): 239-73.
McNulty, R. 1991. Cultural planning: A movement for civic progress. In The cultural planning conference proceedings, edited by Engineering Information Transfer Pty Ltd. Mornington, Victoria, Australia: Engineering Publications.

Mercer, C. 2002. Towards cultural citizenship: Tools for cultural policy and development. Stockholm: The Bank of Sweden Tercentenary Foundation.

Mercer, C. 2006. Cultural planning for urban development and creative cities. http:/www.culturalplanning-oresund.net/ PDF_activities/maj06/Shanghai_cultural_planning_paper.pdf (accessed May 23, 2010).

Mills, D. 2003. Cultural planning-Policy task, not tool. Artwork Magazine May, 55.

Ministry of Local Government, Lands and Housing 1996. National report and plan of action for habitat II. Gaborone, Botswana: Government Printer.

Noppen, D. 1982. Consultation and non-commitment: Planning with the people in Botswana. Leiden, Netherlands: African Studies Centre.

Rapley, J. 1996. Understanding development: 7 'hroly and Prartiw in the Third World. Boulder, CO: Lynne Rienner.

Schapera, I. 1984. A handbook of Tswana law and custom. Oxford: Oxford University Press.

Shoshong Land Board. 2005. The Master Plan of Shoshong 2005. Shoshong, Botswana: Land Board.

Sowa Town Council. 2003. Sowa urban development plan: $2003-$ 2009. Gaborone, Botswana: Government Printer.

Swedeplan and DTRP. 1997. Physical Planning Handbook for Botswana. Gaborone, Botswana: Department of Town and Regional Planning (DTRP).

United Nations Educational, Scientific and Cultural Organization (UNESCO). 1976. Recommendation concerning the safeguarding and contemporary role of historic areas. http://www.icomos. org/unesco/ areas76.html (accessed November 15, 2007).

UNESCO. 2000. Change in continuity: Concepts and tools for a cultural approach to development. Culture, Development and Society Series. UNESCO.

UNESCO. 2003. Convention for the safeguarding of the intangible cultural heritage. http://www.culturelink.or.kr/.../UNESCO_C_1. pdf (accessed July 17, 2007).

Watson, V. 2003. Conflicting rationalities: Implications for planning theory and ethics: Case of Cape Town. Planning Theory and Practice 4 (4): 395-407.

Williams, R. 1958. Culture is ordinary. In Convictions, edited by N. McKenzie, 24-34. London: MacGibbon and Kee.

Williams, R. 1966. Culture and Society, 1780-1950. Harmondsworth: Penguin.

Wåreus, J. 2007. How to care for your culture and identity. Sunday Standards, March 14.

Young, G. (2008). The culturisation of planning. Planning Theory 7 (1): 71-91.

\section{Bio}

Feras Hammami is a doctoral candidate in the Department of Environment and Urban Planning at the Royal Institute of Technology, Stockholm. His research interests are in planning governance and power, with particular focus on conservation of inhabited historic environments. 